\title{
DOLANAN SEBAGAI MEDIA PENDIDIKAN KARAKTER PADA SISWA SEKOLAH DASAR
}

\author{
Oleh \\ Ni Putu Libria Anggraeni \\ SD Pelangi Dharma Nusantara \\ libriaanggraeni@gmail.com \\ Kadek Aria Prima Dewi PF \\ Institut Hindu Dharma Negeri Denpasar \\ primadewipf@gmail.com
}

\begin{abstract}
ABSTRAK
Dolanan merupakan satu permainan tradisional yang diadopsi dari keadaan kehidupan lingkungan sosial kehidupan anak - anak di daerah pedesaan. Dalam Permainan dolanan ada banyak nilai yang dapat dipelajari. Selain itu permainan dolanan ini juga dapat diadopsikan ke dalam sistim pembelajaran yang berbasis budaya, khususnya dalam pembelajaran bahasa Bali. Dari latar belakang tersebut ada beberapa permasalahan yaitu keberadaan Dolanan di era globalisasi dan peran Dolanan sebagai media pendidikan karakter. Dolanan anak tradisional yang hampir punah diperlukan upaya revitalisasi untuk melestarikan berbagai dolanan anak tersebut, seperti pengenalan ulang berbagai jenis dolanan di sekolah melalui media yang menarik. Selain dengan cara itu festival atau lomba dolanan juga perlu diadakan untuk melestarikan dolanan tradisional. Selain untuk melestarikan budaya dolanan tradisional festival atau lomba dolanan tradisional juga bisa. Hilangnya dolanan anak tradisional akan membawa berbagai dampak, terutama terhadap unsur budaya lokal yang sudah ada terlebih dahulu. Dalam hal ini salah satu upaya nyata untuk dapat melestarikan permainan dolanan ini adalah melalui sanggar - sanggar seni. Keberadaan Sanggar Seni Dolanan Anak saat ini sangat dibutuhkan oleh masyarakat untuk melestarikan dan mengembangkan dolanan anak tradisional. Dolanan ini bisa dikategorikan dalam tiga golongan, yaitu : permainan untuk bermain (rekreatif), permainan untuk bertanding (kompetitif) dan permainan yang bersifat edukatif. Permainan tradisional yang bersifat rekreatif pada umumnya dilakukan untuk mengisi waktu luang. Permainan tradisional yang bersifat kompetitif, memiliki ciri-ciri : terorganisir, bersifat kompetitif, diainkan oleh paling sedikit 2 orang, mempunyai criteria yang menentukan siapa yang menang dan yang kalah, serta mempunyai peraturan yang diterima bersama oleh pesertanya. Sedangkan perainan tradisional yag bersifat edukatif, terdapat unsur-unsur pendidikan di dalamnya. Melalui permainan seperti ini anak-anak diperkenalkan dengan berbagai macam ketrampilan dan kecakapan yang nantinya akan mereka perlukan dalam menghadapi kehidupan sebagai anggota masyarakat. Berbagai jenis dan bentuk permainan pasti terkandung unsur pendidikannya. Inilah salah satu bentuk pendidikan yang bersifat non-formal di dalam masyarakat. Permainan jenis ini menjadi alat sosialisasi untuk anak-anak agar mereka dapat menyesuaikan diri sebagai anggota kelompok sosialnya.
\end{abstract}

\section{Kata Kunci : Kearifan Lokal, Media Pembelajaran, Dolanan}




\section{PENDAHULUAN}

Keberhasilan sebuah pembelajaran tidak hanya ditentukan oleh tingginya pendidikan seorang pendidik. Tersedianya sarana dan prasarana pendidikan merupakan salah satu faktor penunjang berhasilnya pembelajaran.

Keterbatasan sarana dan prasarana pembelajaran dapat diatasi dengan memanfaatkan yang ada di lingkungan sekitar. Permainan tradisional daerah juga memiliki potensi besar untuk dimanfaatkan dalam pembelajaran di sekolah dasar. Media pembelajaran dengan menggunakan permainan tradisonal, karena dalam permaianan tradisional mempunyai nilai nilai pengetahuan yang seharusnya dilestarikan oleh guru, sekalipun pada kenyataannya permainan tradisional sedidikit demi sedikit ditinggalkan, permainan tradisional merupakan ciri suatu bangsa, dan hasil suatu peradaban. Bangsa mana yang tidak bangga pada permainan budaya. Karenanya, menggali, melestarikan dan mengembangkan permainan tradisional adalah suatu hal yang tidak dapat dihindari. Selain telah menjadi ciri suatu bangsa, permaian tradisional adalah salah satu bagian terbesar dalam suatu kerangka yang lebih luas yaitu kebudayaan.

Kearifan lokal tidak dapat dilepaskan dari kebudayaan masyarakat yang mendukungnya. Kearifan lokal mencakup semua unsur kebudayaan manusia seperti sistem religi, bahasa, ekonomi, teknologi, pendidikan, organisasi sosial, dan kesenian. Kearifan lokal yang tumbuh dan berkembang dimasyarakat sebagai landasan pembentukan karakter bangsa yang dapat diaplikasikan melalui pendidikan. Pendidikan adalah suatu proses yang dilakukan secara sadar oleh seorang pendidik untuk membentuk karakter peserta didiknya. Pendidikan dapat berlangsung dimana saja secara formal maupun non formal. menurut John Dewey, pendidikan merupakan suatu proses pengalaman. Karena kehidupan merupakan pertumbuhan, maka pendidikan berarti membantu pertumbuhan batin manusia tanpa dibatasi oleh usia. Proses pertumbuhan adalah proses penyesuaian pada setiap fase dan menambah kecakapan dalam perkembangan seseorang melalui pendidikan.Pembentukan karakter dalam pendidikan formal di sekolah dapat dilakukan dalam proses pembelajaran dengan menyelipkan nilai-nilai yang berbasis kearifan lokal. Paulo Freire (1970), menurutnya, pendidikan berbasis kearifan lokal adalah pendidikan yang mengajarkan peserta didik untuk selalu konkret dengan apa yang mereka hadapi. Hal ini sebgaimana Paulo Freire, seorang filsuf pendidikan dalam bukunya Cultural Action for Freedom (1970), menyebutkan dengan dihadapkannya pada problem dan situasi konkret yang dihadapi, peserta didik akan semakin tertantang untuk menanggapinya secara kritis. Oleh karena itu di perlukan adanya integrasi ilmu pengetahuan dengan kearifan lokal.Selain telah menjadi ciri suatu bangsa, permaian tradisional adalah salah satu bagian terbesar dalam suatu kerangka yang lebih luas yaitu kebudayaan. Permainan tempo dulu sebenarnya sangat baik untuk melatih fisik dan mental anak. Secara tidak langsung anak-anak akan dirangsang kreatifitas, ketangkasan, jiwa kepemimpinan, kecerdasan, dan 
keluasan wawasannya melalui permainan tradisional. Namun sayangnya seiring kemajuan jaman, permainan yang bermanfaat bagi anak ini mulai ditinggalkan bahkan dilupakan. Anak-anak terlena oleh televisi dan video game yang ternyata banyak memberi dampak negatif bagi anak-anak, baik dari segi kesehatan, psikologis maupun penurunan konsentrasi dan semangat belajar. Permainan Tradisional yang semakin hari semakin hilang di telan perkembangan jaman, sesungguhnya menyimpan sebuah keunikan, kesenian dan manfaat yang lebih besar seperti kerja sama tim, olahraga, terkadang juga membantu meningkatkan daya otak.

Banyaknya kegunaan permaianan bagi proses pembelajaran perlu adanya pelestarian terhadap keutuhan permaianan tersebut. Mengenal permainan tradisional bermain congklak, tajog, meong - meongan, kasti, dengkleng, dan lain-lain di masa muda, akan mengantarkan mereka pada permainan yang bermamfaat dalam kegiatan belajar untuk meraih prestasi di masa yang akan datang. Pelaksanaan pembelajaran dengan menggunakan permainan tradisional dapat dilakukan dengan memanfaatkan benda-benda yang ada di sekitar. Permainan tradisional juga dapat melatih kesehatan jasmani karena banyak melakukan gerakan gerakan fisik.

Menguatnya arus globalisasi di Indonesia yang membawa pola kehidupan dan hiburan baru, mau tidak mau, memberikan dampak tertentu terhadap kehidupan sosial budaya masyarakat. Termasuk di dalamnya berbagai macam permainan tradisional anak. Sementara itu, kenyataan dilapangan dewasa ini memperlihatkan adanya tanda tanda yang kurang menggembirakan yakni semakin kurangnya permaianan tradisional anak yang ditampilkan, sehingga akan berakibat pada kepunahan. anyaknya kegunaan permaianan bagi proses pembelajaran perlu adanya pelestarian terhadap keutuhan permaianan tersebut. Operasional pelaksanaan pembelajaran dengan menggunakan permainan tradisional dapat dilakukan dengan memanfaatkan benda-benda yang ada di sekitar.

Melalui permainan, berbagai pekerjaannya dapat terwujud dan permainan dapat dipilih oleh anak karena menyenangkan bukan untuk memperoleh hadiah atas pujian dan anak di usia SD adalah masa bermain untuk masa perkembangan selanjutnya, karena dengan bermain anak pada usia SD ini akan menentukan upaya perkembangannya sesuai dengan apa yang di milikinya.

Dalam artikel ini akan dibahas mengenai permainan dolanan sebagai media pendidikan karakter anak - anak khususnya anak - anak yang masih berada pada jenjang sekolah dasar. Dolanan merupakan satu permainan tradisional yang diadopsi dari keadaan kehidupan lingkungan sosial kehidupan anak - anak di daerah pedesaan. Dalam Permainan dolanan ada banyak nilai yangdapat dipelajari. Selain itu permaina dolanan ini juga dapat diadopsikan ke dalam sistim pembelajaran yang berbasis budaya, khususnya dalam pembelajaran bahasa Bali. Dari uraian tersebut sangat jelas dipertanyakan bagaimana keberadaan Dolanan di era 
globalisasi sebagai media pendidikan karakter.

\section{METODE}

Pengumpulan berbagai informasi dan bahan pendukung untu menguatkan tulisan ini diperoleh dari berbagai referensi buku, tulisantulisan yang terkait. Sumber-sumber ini juga akan menjadi bahan-bahan penunjang untuk menyikapi permasalahan yang ada, khususnya mengenai keberadaan Dolanan sebagai media pendidikan karakter belakangan ini.

\section{DOLANAN DI ERA GLOBALISASI}

Dalam kamus bahasa Indonesia dolanan berarti bermain main. Dalam bahasa jawa dolanan berasal dari kata dolan yang mendapat akhiran an berarti bermain. Kata dolanan sebagai kata kerja yaitu 'bermain', sebagai kata benda yaitu'permainan', dan atau 'mainan'. Dolanan anak sering disebut sebagai Permainan tradisonal yang merupakan simbolisasi dari pengetahuan yang turun temurun dan mempunyai bermacam-macam fungsi atau pesan di baliknya, di mana pada prinsipnya permainan anak tetap merupakan permainan anak. Dengan demikian bentuk atau wujudnya tetap menyenangkan dan menggembirakan anak karena tujuannya sebagai media permainan. Aktivitas permainan yang dapat mengembangkan aspek-aspek psikologis anak dapat dijadikan sarana belajar sebagai persiapan menuju dunia orang dewasa.

Kondisi dolanan anak di saat ini sangat memprihatinkan. Hal ini disebabkan oleh banyak faktor, antara lain minat anak-anak terhadap

$\begin{array}{llr}\text { dolanan anak } & \text { tradisional semakin } \\ \text { berkurang } & \text { karena } & \text { adanya } \\ \text { perkembangan } & \text { tekhnologi } & \text { yang }\end{array}$
membawa konsekwensi terhadap munculnya permainan baru dalam beraneka bentuk barang elektronik. Derasnya arus globalisasi yang merambah setiap segi kehidupan, merambah pula dunia anak-anak. Munculnya model-model permainan baru terutama dalam bentuk barang dan online yang diproduksi secara besar-besaran mempengaruhi cara pandang anak-anak sebagai penikmat langsung dari produk permainan ini, sehingga respon terhadap dolanan anak pun menjadi berkurang. Faktor lain yang memberi pengaruh kurangnya respon terhadap dolanan anak adalah berkurangnya media untuk memainkan dolanan anak, diantaranya adalah semakin berkurangnya lahan kosong seperti lapangan, kebun dan tanah kosong yang seringkali beralih fungsi menjadi perumahan dan bangunanbangunan lainnya, sehingga anakanak pun semakin sulit untuk mendapat sarana bermain.

Dolanan anak tradisional yang hampir punah diperlukan upaya revitalisasi untuk melestarikan berbagai dolanan anak tersebut , seperti pengenalan ulang berbagai jenis dolanan di sekolah melalui media yang menarik. Selain dengan cara itu festival atau lomba dolanan juga perlu diadakan untuk melestarikan dolanan tradisional. Selain untuk melestarikan budaya dolanan tradisional festival atau lomba dolanan tradisional juga bisa. Hilangnya dolanan anak tradisional akan membawa berbagai dampak, terutama terhadap unsur budaya lokal yang sudah ada terlebih dahulu. Tentunya hal tersebut sangat tidak kita harapkan, masyarakat Indonesia 
yang ramah tamah dengan solidaritas sosial yang tinggi akan sangat kita idam-idamkan untuk mempertahankan identitas bangsa dan memperkuat diri dalam menghadapi pusaran arus globalisasi. Dalam hal ini salah satu upaya nyata untuk dapat melestarikan permainan dolanan ini adalah melalui sanggar sanggar seni. Keberadaan Sanggar Seni Dolanan Anak saat ini sangat dibutuhkan oleh masyarakat untuk melestarikan dan mengembangkan dolanan anak tradisional. Anak-anak membutuhkan arena untuk bermain, bersosialisasi, berkreatifitas, dan mengembangkan kemampuan motorik mereka.

\section{DOLANAN SEBAGAI MEDIA PENDIDIKAN KARAKTER}

Permainan

tradisional

Dolanan ini bisa dikategorikan dalam tiga golongan, yaitu : permainan untuk bermain (rekreatif), permainan untuk bertanding (kompetitif) dan permainan yang bersifat edukatif. Permainan tradisional yang bersifat rekreatif pada umumnya dilakukan untuk mengisi waktu luang. Permainan tradisional yang bersifat kompetitif, memiliki ciri-ciri : terorganisir, bersifat kompetitif, diainkan oleh paling sedikit 2 orang, mempunyai criteria yang menentukan siapa yang menang dan yang kalah, serta mempunyai peraturan yang diterima bersama oleh pesertanya. Sedangkan perainan tradisional yag bersifat edukatif, terdapat unsur-unsur pendidikan di dalamnya. Melalui permainan seperti ini anak-anak diperkenalkan dengan berbagai macam ketrampilan dan kecakapan yang nantinya akan mereka perlukan dalam menghadapi kehidupan sebagai anggota masyarakat. Berbagai jenis dan bentuk permainan pasti terkandung unsur pendidikannya. Inilah salah satu bentuk pendidikan yang bersifat non-formal di dalam masyarakat. Permainan jenis ini menjadi alat sosialisasi untuk anak-anak agar mereka dapat menyesuaikan diri sebagai anggota kelompok sosialnya.

Pada era ini dolanan hanya bisa ditemui di perhelatan Pesta Kesenian Bali yang diadakan setiap satu tahun sekali. Dolanan anak sudah menjadi hal wajib yang harus ditampilkan oleh duta masing masing kabupaten. Dalam pertunjukan dolanan dimainkan kurang lebih orang sepuluh rang anak. Dimana dalam dolanan tersebut adalah menceritakan tentang kehidupan anak - anak desa yang berkumpul bersama temen temannya untuk bermain bersama sama. Di dalam dolanan tersebut mereka akan bercerita mengenai permainan tradisional daerahnya masing - masing, secara tidak langsung penampilan dolanan tersebut sudah melatih anak - anak untuk cakap dalam berkomunikasi, belajar penggunaan bahasa dalam pergaulan, melatih kerja sama tim yang solid. Selain itu juga melatih anak - anak untuk mengenal lagu lagu tradisional yang semakin jarang diketahui, karena dalam dolanan tersebut akan sifatnya bermain, bernyanyi sambil belajar.

Biasanya dolanan yang dipertontonkan pada Pesta Kesenian Bali akan diiringi dengan tetabuhan (gambelan) sebagai musiknya agar semakin menarik untuk disaksikan, selain itu juga ada Gerong (penyanyi perempuan) yang menyanyikan jalan dari cerita dolanan tersebut.

Dolanan seperti ini baik diterapkan dalam pembelajaran di 
sekolah dasar, karena anak - anak sekolah dasar biasanya akan lebih mengingat materi yang diajarkan guru melalui praktik permainan. Sebagai contoh, guru meginginkan siswa bisa menyanyikan sekar rare, maka dalam dolanan itu mereka akan diberi nyanyian - nyanyian melalui permainan, dan biasanya itu akan lebih diingat daripada harus diajarkan secara teori di kelas. Dalam dolanan itu juga akan terselip nilai - nilai pendidikan karakter.

$\begin{array}{crr}\text { Dolanan } & \text { ini } & \text { dapat } \\ \text { diadopsikan } & \text { sebagai } & \text { media }\end{array}$ pembelajaran, khususnya pembelajaran Bahasa Bali. Karena dalam dolanan ini banyak diajarkan nilai -nilai kearifan lokal masyarakat Bali, yang diajarkan pada anak anak secara tidak langsung melalui media bermain dolanan ini.

\section{SIMPULAN}

Dolanan yang semakin ditinggalkan ini diperlukan upaya revitalisasi untuk melestarikan berbagai dolanan anak tersebut , seperti pengenalan ulang berbagai jenis dolanan di sekolah melalui media yang menarik. Selain dengan cara itu festival atau lomba dolanan juga perlu diadakan untuk melestarikan dolanan tradisional. Selain untuk melestarikan budaya dolanan tradisional festival atau lomba dolanan tradisional juga bisa. Hilangnya dolanan anak tradisional akan membawa berbagai dampak, terutama terhadap unsur budaya lokal yang sudah ada terlebih dahulu. Keberadaan Sanggar Seni Dolanan Anak saat ini sangat dibutuhkan oleh masyarakat untuk melestarikan dan mengembangkan dolanan anak tradisional.
Dolanan baik diterapkan dalam pembelajaran di sekolah dasar, karena anak - anak sekolah dasar biasanya akan lebih mengingat materi yang diajarkan guru melalui praktik permainan. Dalam dolanan itu juga akan terselip nilai - nilai pendidikan karakter. Dari dolanan anak - anak akan belajar menyanyi. Karena konsep dolanan ini adalah bermain, bernyanyi sambil belajar.

\section{DAFTAR PUSTAKA}

Handayani,Titi.2003.Upaya menghidupkan kembali dolanan anak-anak sebagai media pelestarian budaya. Yogyakarta: Sarasehan Menggali Nilai-Nilai Kebangkitan nasional

Larasati, R Diyah. 1997. "Kecak Rina, Sadono, W Kusuma dan ARMA (Kerja Kreatif Seniman Tradisional dan Modern)". Jurnal Seni Pertunjukkan Indonesia Tahun VIII. Bandung: MSPI. Prawiroatmojo,Bausastra Jawa Indonesia,Jakarta,1988. 